\title{
地質学における情報知識学の実践としての情報地質学 Geoinformatics as a Practice of Informational Knowledge in Geology
}

\author{
西脇二一 \\ Niichi NISHIWAKI \\ 奈良大学社会学部
}

Faculty of Social Research, Nara University

T631-8502 奈良市山陵町 1500

E-mail: niichi@daibutsu.nara-u.ac.jp

\section{1 はじめに}

地質情報の特性の解明とそれに対応した 処理技術の開発を目的とする情報地質学

は，地質学分野におけるデータの質と量の 改善とそれによるモデル高度化の流れの中 で，コンピュータを中心とする情報技術の 発展を背景として生まれた。それ以来，地 質学および関連分野における情報を対象と したさまざまな理論的および実用的研究が 進められ, 情報地質学は地質学の新しい分 野としての地位を確立してきた。しかし， 近年におけるネットワークの普及をはじめ とする情報環境の急激な変化は，地質情報 についても新たな対応を要求しており，情 報地質学の今後のあり方が問題となってい る.

情報地質学会の活動内容は，データから 情報を取り出すための理論・技術を開発す る分野と, 情報から法則・論理を取り出し て地質学分野に適用する分野の両方からな っている. 後者はまさに情報知識学の範疇 に入るものであり，情報地質学は地質学分 野で情報地質学を実践していると言えよ う.

本論では，情報地質学について解説する ことにより，地質学における情報知識学の
あり方について考察を行う。

\section{2 情報地質学の誕生}

記載を中心とする伝統的な地質学では, そこで扱われるデータの特性から，データ の検定や統計処理が困難なことが多かっ た. 第二次世界大戦後における地質学の近 代化の中で, データの質と量が変化し, 統 計解析や数理モデルを使つた研究が徐々に 行われるようになった. 1960 年代後半から 大型計算機が利用できるようになってデー 夕解析の動きが加速され, 地質学でも数理 モデルや統計解析を中心とした研究を行う

「数理地質学」という新しい分野が生まれ, 国際数理地質学会(IAMG: International

Association for Mathematical Geology)が設立 された. 国際数理地質学会 ${ }^{[1]}$ は 1968 年プ ラハでの第23 回国際地質学会(IGC:

International Geological Congress)の機会に設 立された. 設立の当初から国際地質学連合 (IUGS: International Union of Geological Sciences) と国際統計研究所 (ISI : International Statistical Institute)に所属していて, 地質学に おける数理モデルの構築とその応用, およ び，地質データの数理処理のための理論と 技術の開発に関する研究が行われている. 
設立以来，地質学の多くの分野における新 しい研究と啓蒙活動を活発に推進し, 数理 地質学は今日では地質学のあらゆる分野で 広く受け入れられるようになっている.

日本で 1970 年代に結成された「情報地質 研究会」では，先行していた数理地質学の 枠には入りきらないものも含めて, 地質情 報に関する研究が進められてきた。すなわ ち, 数理モデルや統計解析だけでなく, 数 值化されていない情報も含めて，地質情報 の収集, 蓄積, 検索, 処理, 表示なども研 究対象とされてきた。情報地質研究会設立 の時点では，コンピュータは主として数值 情報の処理・解析を扱うものでしかなかっ たため, 数理地質学の枠に入りきらない部 分の研究を行うためのハードウェア, ソフ トウェアの環境は整備されておらず, デー タベース関係の部分を除くと, 数理地質学 との差は大きくなかった. しかし，その後 のコンピュータを始めとする情報処理技術 の急速な発展により, 数理地質学の枠外の 部分について研究の可能性が急速に拡大

し，「情報地質学」という新しい学問分野 が成長することとなったのである.

日本における情報地質研究会の設立以前 には，世界的にみても，情報地質学あるい はそれに類似する分野の研究が体系的に進 められたことはなかった。 また, 設立当初 の活動は小規模であったとはいえ，この情 報地質研究会があったからこそ，その後の パーソナルコンピュータやネットワークな どの情報技術の発展に対応できたことを考 えれば，情報地質研究会の設立を以て，情 報地質学の成立と見なすことができよう [2].

\section{3 情報地質学の歴史}

文部省（当時）の特定研究「広域大量情 報の高次処理」 ${ }^{[3]}$ の地質班では, 当初, 地 質情報システム GEODAS の開発を目的と

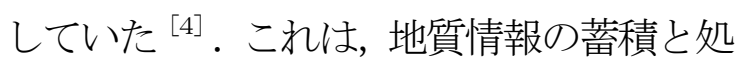
理を総合的に行うデータベースシステム で，その中に地質データの処理・解析のた めのプログラムパッケージ GEOPAK が含 まれていた，このシステムは，当時，よう やく使えるようになってきたミニコンピュ 一タ上で開発が始められ，その後，マイク ロコンピュータの発展に伴って, パソコン 上で稼働するものに改良された.

この特定研究の連絡会としてスタートし た情報地質研究会では，さらに枠を広げて， 地質情報の処理に関わるシステムの開発や その応用に関する研究が進められ，その成 果が機関誌「情報地質」（英文名 Geological Data Processing）に発表された. そこには会 員が開発したプログラムのソースコードも 掲載されると共に，それらはGEOPAKと してフロッピーディスクに収めて希望者に 配布された. 当時は, 地質情報の処理のた めのソフトウェアやプログラムが貧弱で, 実際に処理しようとすると，そのためのプ ログラムを最初から作らねばならないとい う状況であったので, GEOPAK は大変重宝 がられた。

機関誌の購読者を会員とする情報地質研 究会では，当初は独自のシンポジウムを開 くことはなく，会員はそれぞれの研究対象 に関係する学会のセッションで研究成果を 発表するしかなかった。 情報地質研究会に は専門の大きく異なる会員が集まっている ため, 機関誌以外に会員間の意見交換の場 を設けることができなかった.

情報地質研究会では, 日本地質学会の年 
会の際に夜間小集会を開いて情報地質学に 関する情報交換を行ってきたが，単なる情 報交換のみの非公式な会合で，出席者も少 なく，十分な成果はあげられなかった。 日 本地質学会に働きかけた結果，1989 年から は日本地質学会の年会の講演区分に「情報 地質」が設けられ，独自のセッションを持 つことができるようになった。 また，1990 年には日本地質学会の討論会として「情報 地質 : その課題と展望」を開催し, 日本地 質学会としては初めての, パソコンによる デモンストレーションを中心とするポスタ 一セッションが行われた。

情報地質研究会の 15 年間は, パソコンを 中心とする情報技術の発展の時期でもあ り，地質情報の処理にも新しい可能性が次 々と登場してきた。情報地質学の新たな研 究課題が出てきたことで, 20 数人でスター トしだ情報地質研究会の会員数も最大時に は 800 人にまで増加し，会員間における情 報交換の場の確保が重要になってきた。投 稿論文が増え，年 1 回発行の機関誌を 2 冊 に分冊しなければならなくなり，また， GEOPAK のプログラム数も飛躍的に増大 していった. このため, 学会事務をボラン ティアに頼る研究会では対応できなくな り，1990 年に「日本情報地質学会」(Japan Society of Geoinformatics)が設立されること となった.

日本情報地質学会では，ネットワークを はじめとする情報処理に関する理論と技術 の急速な発展の中で，その成果を地質学お よび関連分野に積極的に取り入れた研究が 進められてきた。まだ，技術講習会やシン ポジウムを通して，それらの普及に貢献し てきた，会員が国際会議において研究成果 を発表すると共に，ISME AI '90
(International Symposium on Mineral Exploration The Use of Artificial Intelligence, Tokyo, 1990） ， 29th IGC (29th International Geological Congress, Kyoto, 1992), IAMG '95 (Second Annual Conference of International Association for Mathematical Geology, Osaka, 1995)などの国際会議を主催・後援してき た.これらの結果，学会の英文名にある Geoinformatics という造語が国際的に認め られるようになってきた。

\section{4 情報地質学の発展}

地質学の近代化により大量に集積される ようになった地質情報を処理することを目 的として誕生した情報地質学は，その後の 情報科学の発展に伴って，その対象と手法 を拡大しながら発展してきた。

1970 年代の汎用コンピュータの時代に は，数值情報の処理が中心で，文字情報に ついはごく限られた処理しかできず，デ 一タ保存のためのメディアの種類や記憶容 量も限られており，利用のための時間や方 法も限定されていた. また，ソフトウェア も揃っておらず，最初からプログラミング しなければ何もできない状態であった。 そ のため, 地質情報についても，数值情報の 統計処理や数理モデルについての研究が中 心で，数值情報以外についてはごく限られ た処理しか行えなかった。

1980 年代のパソコンの時代になると, 数 值以外の情報も扱え，個人利用で時間の制 約がなくなったことで，処理速度が遅いな がらも相当の処理ができるようになった. パソコンの処理速度や記憶容量は急速に改 善され，また，MS-DOS 環境下でのソフト ウェアの整備も進んだ. 地質情報について 
も，それまでは処理できなかった画像情報 を含めた多様な情報が扱えるようになり， 蓄積・解析・表示などのための多様なソフ トウェアやシステムが開発されるようにな ってきた。

1990 年代になると, パソコンの能力が大 幅に改善されると共に, WINDOWS 環境下 でのソフトウェアの標準化と，インターネ ットを中心とするネットワークの整備が進 み，異種類の情報を統一的に処理できるよ うになった．地質情報についても，扱われ る情報の種類と量が大きく拡大寸ると共 に，その処理のための手法についても高度 かつ多様なものが使えるようになり，GIS 技術を導入した地質情報の統合処理に関わ る研究や, 人工知能やエキスパートシステ ムなどの高度な手法を応用した研究が行わ れるようになってきた。

2000 年代になるとネットワーク環境の 急速な発展・普及に伴って，地質情報のグ ローバル化が進行してきた. オープンソフ トウェアの開発・利用による技術の共有化, Web-GIS 技術を用いた地質情報のネットワ ーク上での共有, One Geology 計画による 世界標準による地質図の標準化などの動き が活発化している. 情報地質学はこのグロ 一バル化の流れの中で，地質情報の普及と セキュリティについても責任を求められて いる.

\section{5 情報地質学の内容}

情報地質学は, 地質学および関連分野の あらゆる情報を研究対象とし，その収集か ら，蓄積，検索，解析，表示までのあらゆ る処理に関する研究を行うものである。そ こでは，情報科学および関連分野のあらゆ
る手法が導入されており，理論・技術の発 展につれて，常に新しい手法が検討されて いる．以下に地質情報の流れに沿って，現 在の情報地質学の具体的な研究内容を見て みよう。

\section{1 地質情報の収集に関わる研究}

地質情報は，時間を含めた 4 次元空間に 分布すること，発生した事象は取り消しで きないという歴史性を持つこと，事象の発 生には確率過程の要素が含まれること, 定 性的にしか記述できない変数が多いこと， などの特性があり，情報の収集の段階から， その特性に対応した取り扱いが必要であ

る. 近年，地質情報についても機器による 自動計測・自動分析が広く多く行われるよ うになっており，その後の情報処理を考慮 して情報を収集することが大切である。情 報地質学では, 情報の収集段階も研究対象 であり, 必要に応じて情報収集のための八 ードも研究することになる.

\section{2 地質情報の蓄積に関わる研究}

近年では, 各種のデータベースのための ソフトウェアが充実してきて, 地質関係で もデータベースの整備が進められ, 収納さ れたデータが実際の研究に利用されること が多くなっている．また，データベースの 構築の過程で地質情報のデータ構造が解析 され，新しい地質モデルの構築に役立って いる例も多い，しかし，地質情報のもつ特 性から，地質情報は蓄積および検索にあた っても既存のソフトウェアや手法では対応 が困難なことも多い。また，インターネッ 卜を中心とする近年の情報環境の中では， 学術情報もインターネット上で利用できる ことが必要になっている. GIS 技術の発展 により地質関係のデータベースをインター ネット上で公開するための技術的・制度的 
問題はかなり解決されたが，地質情報の特 性に対応した適切な蓄積と検索のための新 しい手法やシステムの開発を続けることが 必要である.

\section{3 地質情報の解析に関わる研究}

情報地質学は地質情報の処理そのものを 目的とするのではなく，それによって地質 学分野の課題を解決することを目的として いる. 数理地質学が主として扱っている地 質情報の解析，モデル化，シミュレーショ ンなどは，情報地質学にとっても重要な研 究分野である. 情報地質学では，これらに 関する理論の開発，理論の応用，システム の開発，システムの利用技術などの研究を 行っている. 数理地質学では前二者に重点 があるのに対し，情報地質学ではこれら四 者はすべてが重要である。近年，情報環境 の整備が進み，多くの情報処理システムが 利用可能になってきているが，利用技術の 開発・普及が遅れていて，せっかくの新し いシステムが十分に使われていない状況を 考えれば，既存システムの利用技術に関す る研究も重要である.

\section{4 特定種別の情報の処理に関する研 究}

地質情報には多くの画像情報が含まれて おり, 多くの画像情報の処理・解析・表示 に関する研究が情報地質学の中で行われて きた.この分野の研究では, 研究報告の中 で特定の地質学分野の課題がまったく扱わ れていないか、扱われていても単なる例で しかないことも多かったため, 従来の地質 学の中でこの分野の研究が紹介されること はほとんどなかった。しかし，画像情報の 処理によって，地質情報の処理の可能性が 大きく広がったことを考えれば，これらも 情報地質学にとっては必要である。画像情
報の例のように，地質情報に含まれる特定 種別の情報の処理法そのものの研究も, そ れが地質情報に関係する限り，大切なもの である.

\section{5 情報処理のアルゴリズムに関する研 究}

地質情報の解析に利用できるアルゴリズ ムの研究も, 情報地質学にとっては重要な 一分野である.このようなアルゴリズムに 関する研究では，地質学分野の課題や情報 を特定することなく，アルゴリズムのみが 扱われることが多い，数理地質学には，地 質学とはまったく関係のない数学者も参加 していて，その研究報告だけではその成果 が地質学でどのように利用されるか理解し かねるものもあるが，それが後日重要なモ デルとなった例が少なくない，将来におけ る情報地質学の発展のためには，同様な研 究成果についても，それが地質情報処理の いずれかの段階で利用される可能性がある 限り, 受け入れていくことが必要である.

\section{6 情報処理の新しい概念・システムに 関する研究}

過去 30 年間の情報処理の理論と技術の 発展のおかげで，それまで困難であった地 質情報も処理できるようになってきたこと を考えれば，情報処理の新しい概念やシス テムの研究も情報地質学の重要な分野であ る.そのような新しい概念やシステムにつ いては，研究の初期の段階では地質学分野 とはまったく関係のない分野しか扱われて こなかったことも多いが，いずれ地質学分 野でも応用される可能性があるものであれ ば，情報地質学では積極的に受け入れて， その地質学分野への応用について研究を進 めるべきである.

\section{7 論理地質学に関する研究}


地質学では経験が重視され，そこで使わ れている公理や法則について, 論理的に検 討されることは少なかった. 論理地質学は, 地質図の自動作画や，地質構造の自動推定 などのための基礎として必要なもので，情 報地質学の重要な分野である. 将来におけ る地質情報の統合の際には，情報間の関係 を明確にしていかねばならず，そのために も地質学における論理そのものの研究は大 切である.

\section{8 文献データ·地質図データに関する 研究}

地質情報には，観測・計測などの一次情 報から，それらを処理した結果，さらにそ れをコンパイルした情報など多くのレベル がある，地質文献や地質図などは，高次の 情報の典型であるが，それらの処理を扱う 研究も情報地質学の重要な分野である.こ れらは，以前は文献情報ということで, 数 值などの情報とは別に扱わねばならなかっ たが，情報技術の発展で両者を統合して扱 うことができるようになったものである. 現在, デジタル地質図に関する国際基準を まとめる作業が続けられており，世界の地 質困が同一基準で作成・利用できるように するための処理法の開発が必要である.

\section{6 情報知識学としての課題}

情報地質学はこれまで，情報科学の発展 に伴ってその対象と手法を拡大しながら発 展し，その時代毎の情報処理環境の中で, 地質情報の可能性を追求し, それによって 地質学分野の発展に貢献してきた. そこに は情報から法則やルールを抽出し, 学問や 社会の発展に寄与するという情報知識学の 活動が多数含まれている. 以下に情報知識
学の視点から, 今後の情報地質学の課題を 検討してみる.

\section{1 地質情報の特性の解明}

情報技術の発展により，処理できる地質 情報の範囲が拡大されるので，これまで扱 われてきた部分に加えて，新たに処理可能 となった地質情報についても，その構造や 特性を解明し，地質情報の効率的処理を可 能とすると共に，その採取法や記載法など についても提言を行うことが必要である. この研究は，単に地質情報の効率的処理と いう実用上の問題としてだけではなく, 地 質学そのものの本質を明らかにするもので もあり，地質学における情報知識学の実践 であるといえよう。これまで経験的に使わ れてきた地質学の法則や分類体系などにつ いても，情報知識学の新しい理論・手法を 用いて検証することが必要である.

\section{2 地質情報の解析に関わる研究}

処理可能な地質情報の範囲が拡大すると いうことは，対象となる地質課題も拡大す ることである．新たな課題の解決のための 新たな理論や解析法の開発を含め, 地質情 報の解析に関する研究は，今後とも続けら れねばならない. 数理関係の解析に関して は数理地質学と共同して研究を進め, 地質 学分野における数理モデルの高次化に貢献 することが大切である. システム開発やシ ステム利用法なと，数理関係以外の部分の 研究については，それぞれの地質学分野と 共同しながら，情報地質学が主体となって 進めなければならない.この解析のプロセ スは情報知識学の基礎的作業と位置づけら れるものである。

\section{3 地質情報の特性に対応した処理法 の研究}

今後, 情報技術が進歩する中で，地質情 
報についても，情報の蓄積，変換，交流な どの一般的な情報処理の枠内で処理できる 部分が多くなり，地質情報の処理がさらに 進むことが期待される。しかし，それらは 必ずしも地質情報の特性を考慮したもので はないので，そのままでは地質情報が扱え ないことや，地質情報の重要な部分が失わ れてしまう危険性もある．地質情報の特性 に対応したシステムへの改良と利用技術の 開発を続けることで，地質情報に含まれる すべての情報を損なうことなく，地質情報 の高次利用に貢献することが必要である. さらに，これらの研究成果が他の分野の情 報処理にも活用され，一般的なシステムそ のものの改良に繋がることも十分予想され る. このシステム開発は情報知識学の範疇 には入らないかも知れないが，情報知識学 を支える技術として必要なものである.

\section{7 おわりに}

情報地質学は, 情報学の広範な知識と技 術を適用して，地質学分野の情報を総合的 に取り扱うものである. 刘象は広義の地質 学分野および関連分野と広く考え, 地質情 報の特殊性に関連した研究であればすべて 含まれる．地質情報に限定されない一般的 な情報処理の理論・技術に関する研究でも， それが地質学分野に応用できるものであれ ばすべて含まれる，地質情報の処理に関わ るものであれば，理論やソフトウェアだけ
ではなく,ハードに関わる研究も含まれる。 地質情報のグローバル化が進むことを考え れば，地質情報およびその処理については 国際的な基淮に従うと共に，国際的な活動 にも積極的に参加していくことが大切であ る.

情報地質学はあくまでも地質学の一分野 であり，その活動の目的は地質学の発展と その社会への貢献である. しかし，その活 動の中心には，情報から知識を取り出し， それを学問・社会の発展に利用していくと いう情報知識学の活動がある. 情報地質学 が，地質学分野における情報地質学の実践 として，今後も大いに成果を上げていくこ とを期待するものである.

\section{文献}

[1] 弘原海清・西脇二一：「国際数理地質 学協会, COGEODATA の活動と日本の対 応」, 日本地質学会編「日本の地質学 100 年」, pp. 449-450, 1993.

[2]弘原海清: 情報地質学の歩夕と展望」, 情報地質，Vol. 1, No. 1，pp. 25-29, 1990.

［3］島内武彦・北川敏男（編）：「広域大 量情報の高次処理」，東京大学出版会， p. 1354, 1977.

[4] 弘原海清：「地質科学用データ・ベー ス・システム (GEODAS) の背景とシステ 么概念. GEODAS の解説，その $1 」 ，$ 情報 地質，No. 1，pp. 8-12, 1975. 